\title{
A Novel Strategy to Enhance Mesenchymal Stem Cell Migration Capacity and Promote Tissue Repair in an Injury Specific Fashion
}

\author{
C. Xinaris,* M. Morigi, * V. Benedetti,* B. Imberti,* A. S. Fabricio, $\dagger$ \\ E. Squarcina, $\neq$ A. Benigni,* E. Gagliardini,* and G. Remuzzi*§ \\ * "Mario Negri” Institute for Pharmacological Research, Bergamo, Italy \\ $\nmid$ Regional Center for Biomarkers-ABO Foundation, Venice, Italy \\ $\ddagger$ Istituto Oncologico Veneto (IOV)-IRCCS, Padova, Italy \\ $\S$ Unit of Nephrology and Dialysis, Azienda Ospedaliera Ospedali Riuniti di Bergamo, Bergamo, Italy
}

\begin{abstract}
Mesenchymal stem cells (MSCs) of bone marrow origin appear to be an attractive candidate for cell-based therapies. However, the major barrier to the effective implementation of MSC-based therapies is the lack of specific homing of exogenously infused cells and overall the inability to drive them to the diseased or damaged tissue. In order to circumvent these limitations, we developed a preconditioning strategy to optimize MSC migration efficiency and potentiate their beneficial effect at the site of injury. Initially, we screened different molecules by using an in vitro injury-migration setting, and subsequently, we evaluated the effectiveness of the different strategies in mice with acute kidney injury (AKI). Our results showed that preconditioning of MSCs with IGF-1 before infusion improved cell migration capacity and restored normal renal function after AKI. The present study demonstrates that promoting migration of MSCs could increase their therapeutic potential and indicates a new therapeutic paradigm for organ repair.
\end{abstract}

Key words: Mesenchymal stem cells (MSCs); Migration; Insulin-like growth factor-1 (IGF-1); Acute kidney injury (AKI); Kidney repair

\section{INTRODUCTION}

The last decade has witnessed an explosion of studies exploring the therapeutic potentials of mesenchymal stem cells (MSCs) for a variety of diseases and disorders $(3,29)$. MSCs can be easily isolated from adult tissues and expanded in vitro without losing their phenotypic characteristics, they are free of ethical controversies and most importantly exhibit no significant immunogenicity, which permits allogenic transplantation without immunosuppressive drugs. Although MSCs were initially considered for therapies based on their multilineage differentiation capacity $(2,34)$, the ability to secrete cytokines and growth factors with antiapoptotic and proangiogenic properties $(14,26,42,47)$ and their capacity to reduce scarring and inflammation (46) have positioned MSCs in the focus of a broad range of emerging therapeutics $(7,9,13,18,24,33)$. However, clinical studies targeting various pathologies have repeatedly provided controversial results. For example, the beneficial effects of MSCs to treat myocardial infarction are not consistent when comparing data obtained from short-term (11) and long-term (27) follow-ups, while ongoing clinical trials for graft-versus-host disease (GvHD) presented mixed clinical data $(23,28)$.

Presently, the major limitations that contribute to the failure of clinical trials are mainly the lack of specific homing after systemic infusion, and potentially, the poor survival of MSCs in the proinflammatory microenvironment of injured tissue. Given the low efficacy of MSCs, a high dosing, ranging from 150 million to 300 million cells administered twice per week over the course of 2 weeks, is usually used in clinical trials (17). High dosing entails extensive in vitro expansion, which is known to induce cell enlargement, potentially elevating the risk of entrapment of cells within nonspecific tissues. Thus, a large fraction of systemically infused MSCs becomes massively trapped within the lungs and filtering organs as emboli $(4,20)$. Alternatively, they passively arrest and interrupt blood flow during the first pass through the precapillary level (44), thus preventing the majority of infused MSCs from homing to damaged or diseased tissues.

Received January 26, 2011; final acceptance April 30, 2012. Online prepub date: August 10, 2012.

Address correspondence to Christodoulos Xinaris, Ph.D., "Mario Negri" Institute for Pharmacological Research, Centro Anna Maria Astori,

Science and Technology Park Kilometro Rosso, Via Stezzano 87, 24126 Bergamo, Italy. Tel: +39-035-42131; Fax: +39-035-319331;

E-mail: cxinaris@yahoo.com; christodoulos.xinaris@marionegri.it 
Various strategies are being developed to reduce the number of administered cells by enhancing cell homing to target tissues or prolonging the presence of the cells in the tissue of interest (45). Genetic modification of MSCs with retroviral vectors encoding homing receptors such as $\mathrm{C}-\mathrm{X}-\mathrm{C}$ chemokine receptor type 4 (CXCR4) or the $\alpha 4$ subunit of the very late antigen-4 (VLA-4)-integrin has been recently used to enhance homing of MSCs $(5,8,21)$. Furthermore, enzymatic conversion of native CD44 glycoform on MSC membrane into hematopoietic cell E-selectin/L-selectin ligand (HCELL) enabled intravenously infused MSCs to home bone marrow more efficiently than unmodified cells (36). Genetically modified MSCs with the serine protease kallikrein by adenovirus transduction were more resistant to oxidative stress-induced apoptosis and enhanced protection against acute ischemic kidney injury by inhibiting apoptosis and inflammation (10). Although genetic modification may be a viable approach to improve cell homing and/or survival, current methods raise potential safety concerns and are technically convoluted and incapable to accommodate a broad range of ligands and factors or are not adaptable to multiple cell types.

Here we attempted to develop an alternative approach to optimize MSC migration efficiency and potentiate their beneficial effect at the sites of the injury. To this direction, we focused on preconditioning MSCs before infusion with various compounds possessing prosurvival and promigratory properties and potentially devoid of side effects. Among the molecules that have been tested for their promigratory properties was Glial cell-derived neurotrophic factor (GDNF), shown to increase the motility and survival of cultured kidney-derived MSCs (39) and tumor necrosis factor- $\alpha$ (TNF- $\alpha)$, reported to improve migration of cultured MSCs towards chemokines (35) and enhance MSC homing into the ischemic myocardium (38). Another possible candidate examined for its promigratory properties was insulin-like growth factor-1 (IGF-1), which proved to mediate the beneficial effect of MSCs on tubular cell repair in acute kidney injury (AKI) (16) and to enhance the migratory capacity of MSCs in vitro (25). Hence, we initially examined the capacity of these molecules to exert promigratory effect on MSCs by using an in vitro injury-migration model, and subsequently, we evaluated the viability of the method in a cisplatin-induced AKI model.

Our results indicated that preconditioning with IGF-1 before infusion markedly increases the number of MSCs homing the injured kidney, thereby ameliorating renal structure impairment and promoting the recovery of renal function.

\section{MATERIALS AND METHODS}

Chemicals were from Sigma-Aldrich (St. Louis, MO, USA) unless otherwise specified.

\section{Isolation and Purification of MSCs}

MSCs were obtained from 2-month-old male C57BL6/J mice (Charles River Italia S.P.A., Calco, Italy) as previously described (29). Briefly, mice were killed, and femurs and tibias were aseptically removed. Bone marrow (BM) was flushed from the shaft of the bone with Dulbecco's modified Eagle's medium (DMEM) containing 2\% fetal calf serum (FCS; Invitrogen, Paisley, Scotland) plus penicillin/ streptomycin (100 U/ml to $0.1 \mathrm{mg} / \mathrm{ml}$; Invitrogen) and then filtered through a 100- $\mu \mathrm{m}$ sterile filter (BD Falcon, Oxford, UK). Filtered BM cells were plated in DMEM plus $10 \%$ FCS and penicillin/streptomycin $(100 \mathrm{U} / \mathrm{ml}$ to $0.1 \mathrm{mg} / \mathrm{ml})$ and allowed to adhere for $6 \mathrm{~h}$. MSCs were recovered from $\mathrm{BM}$ by their tendency to adhere tightly to plastic culture dishes and nonadherent cells were then removed.

After 10-12 days MSCs were immunodepleted of CD45-positive cells as previously described (29). Medium was changed regularly every 3 days; after 10 days, cells were switched to $2 \% \mathrm{FCS}, \mathrm{o} / \mathrm{n}$ and incubated with IGF-1 (20 ng/ ml; StemCell Technologies, Vancouver, Canada), GDNF (100 ng/ml; Abcam, Cambridge, UK), or TNF- $\alpha$ (100 ng/ $\mathrm{ml})$ and detached by trypsin-EDTA $(0.5-0.2 \mathrm{~g} / \mathrm{L}$; Invitrogen $)$ to be used for the in vivo and in vitro experiments.

\section{Migration Assays}

Scrape-Healing Assay. MSCs were seeded at $3.5 \times 10^{4}$ cell $/ \mathrm{cm}^{2}$ in medium containing $10 \%$ FCS and were allowed to reach confluence. Subsequently, they were switched to $2 \% \mathrm{FCS}$ and incubated with IGF-1 $(20 \mathrm{ng} / \mathrm{ml})$ for $36 \mathrm{~h}$, GDNF (100 ng/ml), or TNF- $\alpha$ (100 ng/ml) for $24 \mathrm{~h}$. The monolayers were then scratched by the tip of a pipette, washed with phosphate-buffered saline (PBS), and incubated in $2 \%$ FCS for $20 \mathrm{~h}$ in the presence of the factors apart from TNF- $\alpha$. Images of cell samples were taken by a digital camera. In additional experiments culture medium was removed and adherent cells were harvested and counted $20 \mathrm{~h}$ after scratching. For CXCR4 inhibition experiments, MSCs were treated with IGF-1 (20 ng/ml) for $36 \mathrm{~h}$, exposed to CXCR4 neutralizing antibody ( $5 \mu \mathrm{g} /$ $\mathrm{ml}$; R\&D Systems, Inc., Minneapolis, MN, USA) for $1 \mathrm{~h}$ and then submitted to the scrape-healing assay at the presence of the antibody. For individual cell motility analysis, MSCs were cultured in 24-well plates (BD Falcon) and pictures were taken every hour for $20 \mathrm{~h}$ using a time-lapse microscope (Carl Zeiss, Jena, Germany) equipped with a humidified chamber with $5 \% \mathrm{CO}_{2}$ at $37^{\circ} \mathrm{C}$. Analysis of cell motility was performed on sequential time-lapse images with AxioVision software (Carl Zeiss). Briefly, each individual cell was tracked, and the following features were measured: distance (the total distance in pixels traveled from the first to last timepoint), straight distance (the straight line connecting the first and last time point), cellular velocity (the traveled pixels/min). 
Transfilter Assay. Cell migration was also studied in Transwell chambers (Corning, Costar Italia) by seeding MSCs $(n=3)$ unstimulated or pretreated with IGF-1 (20 ng/ml, $36 \mathrm{~h})(n=3)$, GDNF (100 ng/ml, $24 \mathrm{~h})(n=3)$, or TNF- $\alpha(100 \mathrm{ng} / \mathrm{ml}, 24 \mathrm{~h})(n=3)$ on the upper side of a porous polycarbonate membrane (pore size: $8 \mu \mathrm{m}$; Euroclone S.p.A., Pero, Italy) in coculture with murine proximal tubular epithelial cells (PTECs). PTECs were provided by Dr. Eric G. Neilson (Vanderbilt University, Nashville, TN) and grown as previously described (16). PTECs were seeded at $4.6 \times 10^{4}$ cells $/ \mathrm{cm}^{2}$ and $24 \mathrm{~h}$ later incubated with DMEM plus $2 \%$ FCS (test medium) alone or in the presence of $2.5 \mu \mathrm{M}$ cis-platinum (II)-diamine dichloride (cisplatin; Ebewe Italia srl, Rome, Italy) for $6 \mathrm{~h}$. After cisplatin removal, cells were washed and cocultured with MSCs. Twenty-four hours later, the cells at the upper side of the filter were mechanically removed. Cells that had migrated to the lower side of the filter were fixed for $30 \mathrm{~min}$ in $11 \%$ glutaraldehyde and stained with hematoxylin and eosin (BioOPtica, Milan, Italy). Ten random fields were counted for each filter. The concentration and time of GDNF incubation were chosen on the basis of previous studies (39). Experimental conditions for IGF-1 and TNF- $\alpha$ treatment were based on previous studies $(25,35,38)$ and optimized as follows: MSCs were treated with 10 or $20 \mathrm{ng} / \mathrm{ml}$ of IGF-1 for 24, 36, and $48 \mathrm{~h}$ and 1.0, 10 , or $100 \mathrm{ng} / \mathrm{ml}$ of TNF- $\alpha$ for $24 \mathrm{~h}$. The selected conditions for IGF-1 were $20 \mathrm{ng} / \mathrm{ml}$ for 24 and $36 \mathrm{~h}$ and for TNF- $\alpha 100 \mathrm{ng} / \mathrm{ml}$ for $24 \mathrm{~h}$.

\section{In Vivo Experiments}

C57BL6/J female or male mice, 2 months of age at the start of the experiments, were used. Animal care and treatment were conducted in conformity with the institutional guidelines that are in compliance with national (D.L. n.116, G.U., suppl 40, 18 Febbraio 1992, Circolare No. 8, G.U., 14 Luglio 1994) and international laws and policies (EEC Council Directive 86/609, OJL 358, Dec 1987; U.S. National Institutes of Health Guidelines). Animals were housed in a constant temperature room with a 12-h dark12-h light cycle and fed a standard diet. AKI was induced in female mice by subcutaneous injection of cisplatin $(18 \mathrm{mg} / \mathrm{ml})$ dissolved in sterile $0.9 \%$ saline solution. The dose of cisplatin was chosen on the basis of preliminary experiments, and the highest sublethal dose was used.

To study intrarenal localization and perform quantification of MSCs, $2 \times 10^{5}$ cells were labeled with PKH-26 (16) red fluorescence cell linker and then were infused in cisplatin-treated mice, which were sacrificed at 1 day. Before injection, MSCs were preconditioned with IGF-1 $(20 \mathrm{ng} / \mathrm{ml})(n=3)$, GDNF $(100 \mathrm{ng} / \mathrm{ml})(n=3)$, or TNF- $\alpha$ $(100 \mathrm{ng} / \mathrm{ml})(n=3)$ for $24 \mathrm{~h}$. Labeling efficacy of PKH26-labeled MSCs was $>98 \%$. Viability, evaluated by trypan blue exclusion, was $>96 \%$.
For renal morphology and function studies, female C57BL6/J mice were divided in three groups and, 1 day after cisplatin administration, received an intravenous (IV) injection as follows: group 1 , saline $(n=6-8)$; group 2, $2 \times 10^{5}$ MSCs derived from bone marrow of male C57BL6/J mice ( $n=6-8)$; group 3, $2 \times 10^{5} \mathrm{MSCs}$ preconditioned with IGF-1 $(n=6-8)$. Before injection, MSCs were incubated for $24 \mathrm{~h}$ with IGF-1 (20 ng/ml). Mice were killed at 4 days after cisplatin injection, and blood samples for blood urea nitrogen (BUN) determination were collected before (day 0) and at day 4 after cisplatin administration. Renal function was assessed as BUN in heparinized blood by the Reflotron test (Roche Diagnostics, Indianapolis, IN). BUN levels in control animals averaged $17.4 \pm 0.78 \mathrm{mg} / \mathrm{dl}$. Kidneys were taken at day 4 for histological and ultrastructural analysis.

\section{Quantification of MSC Engraftment in Renal Tissue}

Kidney samples were fixed in $4 \%$ paraformaldehyde (Electron Microscopy Sciences, Hatfield, PA), embedded in 30\% sucrose/PBS and in Tissue-Tek OCT Compound (Sakura Finetek, Torrance, CA), and then fresh-frozen in liquid nitrogen. Three-micrometer-thick sections were fixed in acetone (10 $\mathrm{min})$ and incubated with fluorescein isothiocyanate (FITC)-labeled lectin wheat germ agglutinin (WGA; Vector Laboratories, Burlingame, CA), which binds membrane glycoproteins and sialic acid and was used to identify renal structures. Nuclei were stained with 4,6-diamidino-2phenylindole dihydrochloride hydrate (DAPI). Fifteen sections per mouse were analyzed, and both $\mathrm{PKH}-26^{+} \mathrm{MSCs}$ and $\mathrm{DAPI}^{+}$renal cells were counted in each field. Data were then expressed as number of PKH-26-positive cells per 100,000 renal cells. Stem cell engraftment was also evaluated in heart, lungs, brain, and liver.

\section{Light Microscopy}

Fragments of renal cortex were fixed in Dubosq-Brazil (DDK Italia, Milan, Italy) and embedded in paraffin. Sections of 3- $\mu \mathrm{m}$ thickness were stained with hematoxylin and eosin, Masson's trichrome, or periodic acid-Schiff (PAS) reagent (all from BioOptica, Milan, Italy). Luminal hyaline casts and tubular cell degenerative changes (cytoplasmic vacuolization, swelling, cell flattening, PAS-positive droplets, nuclear fragmentation, cell debris), and cell loss (denudation of the tubular basement membrane) were assessed in nonoverlapping fields (up to 20 fields for each mouse) of the entire section taken at high magnification of $400 \times$ (high-power field, HPF). Number of casts and tubular profiles showing necrosis were recorded in a single-blind fashion.

\section{Immunofluorescence Analysis}

MSCs seeded on glass coverslips at $2.5 \times 10^{4} \mathrm{cell} / \mathrm{cm}^{2}$ in $10 \%$ FCS medium were switched to $2 \%$ FCS plus 
IGF-1 $(20 \mathrm{ng} / \mathrm{ml})$ for $24 \mathrm{~h}$ and then fixed in $2 \%$ paraformaldehyde plus $4 \%$ sucrose and permeabilized with $0.3 \%$ Triton X-100. After incubation with blocking solution ( $2 \%$ fetal bovine serum, $2 \%$ bovine serum albumin, and $0.2 \%$ bovine gelatin in PBS), cells were incubated overnight at $4{ }^{\circ} \mathrm{C}$ with rat anti-mouse CXCR4 antibody (R\&D Systems) followed by the secondary antibody FITCconjugated goat anti-rat IgG (Jackson Immunoresearch, West Grove, PA) and then with $20 \mathrm{U} / \mathrm{ml}$ rhodamine phalloidin (Molecular Probes, Inc., Eugene, OR) for $20 \mathrm{~min}$. Finally, cells were treated with the nuclear cell marker DAPI for $15 \mathrm{~min}$ at $37^{\circ} \mathrm{C}$. Coverslips were washed, mounted in $1 \% \mathrm{~N}$-propyl-gallate in $50 \%$ glycerol and $0.1 \mathrm{~mol} / \mathrm{L}$ Tris-HCl, pH 8, and examined using a confocal inverted laser microscope (LSM 510 Meta, Zeiss). Fifteen fields, systematically digitized along the adhesion surface, were acquired using a computer-based image analysis system. The fluorescent area was evaluated by automatic edge detection using built-in specific functions of the software Image $\mathbf{J}$ (NIH, Bethesda, MD) and expressed as pixel $^{2}$ per field analyzed.

To study cytoskeletal architecture, cells were incubated with IGF-1 (20 ng/ml) for $36 \mathrm{~h}$, GDNF (100 ng/ $\mathrm{ml})$, or TNF- $\alpha(100 \mathrm{ng} / \mathrm{ml})$ for $24 \mathrm{~h}$. Fixed cells were permeabilized, saturated in blocking solution for $30 \mathrm{~min}$, and incubated overnight at $4^{\circ} \mathrm{C}$ with polyclonal goat antivimentin antibody (Santa Cruz Biotechnology, USA, CA). Then cells were incubated with FITC-conjugated rabbit anti-goat (Jackson Immunoresearch) for $1 \mathrm{~h}$ at room temperature (RT). To visualize F-actin filaments, cells were further incubated with $20 \mathrm{U} / \mathrm{ml}$ rhodamine phalloidin (Molecular Probes, Inc.) for $20 \mathrm{~min}$; negative control experiments were also performed. At the end of incubation, cells were treated with DAPI, mounted, and examined microscopically.

\section{FACS Analysis}

For fluorescence-activated cell sorting (FACS) analysis of CXCR4 surface expression, cell suspensions of MSCs untreated or preconditioned with IGF-1 (20 ng/ $\mathrm{ml})$, GDNF (100 ng/ml), or TNF- $\alpha(100 \mathrm{ng} / \mathrm{ml})(n=3)$ for $24 \mathrm{~h}$ were incubated with rat anti-mouse CXCR4 (R\&D Systems) in blocking solution for $30 \mathrm{~min}$. IgG2b was used as negative control. The incubation of the secondary antibody was performed using FITC-conjugated goat anti-rat IgG (Jackson Immunoresearch) for $1 \mathrm{~h}$ at RT, and cells were detected by FACS (Becton Dickinson, Franklin Lakes, NJ).

\section{Western Blot Analysis}

Adherent cells were rinsed with cold PBS plus 0.1 $\mathrm{mmol} / \mathrm{L}$ sodium orthovanadate and lysed in hot sodium dodecyl sulfate (SDS) sample buffer. Whole-cell lysates were separated by SDS polyacrylamide gel electrophoresis and transferred onto nitrocellulose filters (VWR International PBI Srl, Milan, Italy). Blots were blocked with $2 \%(\mathrm{w} / \mathrm{v})$ ECL Advance blocking agent (ECL TM Advance, GE Healthcare, UK) in TBS-T [25 mmol/L Tris- $\mathrm{HCl}$ (pH 7.2), $150 \mathrm{mmol} / \mathrm{L} \mathrm{NaCl}, 0.1 \%$ Tween 20] for $2 \mathrm{~h}$ at RT. Then filters were incubated with rabbit anti-CXCR4 antibody (1:500; Abcam), which recognises two bands, one at about $39 \mathrm{kDa}$ corresponding to the monomer and one at about $78 \mathrm{kDa}$ corresponding to the dimer (1) or with rabbit anti-actin $(1: 10,000)$ antibodies overnight. Finally, blots were incubated with peroxidase-conjugated anti-rabbit antibody (1:40,000; Sigma-Aldrich) to reveal immunoreactive bands using the enhanced chemiluminescence detection system (ECL ${ }^{\mathrm{TM}}$ Advance).

\section{Assessment of Cell Viability and Apoptosis}

MSCs seeded in triplicates into 12 -well plates were exposed to medium alone or IGF-1 $20 \mathrm{ng} / \mathrm{ml}$ for $24 \mathrm{~h}$ and further incubated with $200 \mu \mathrm{M} \mathrm{H}_{2} \mathrm{O}_{2}$ for $24 \mathrm{~h}$. Adherent and floating cells were collected and counted with a cell counter (Digital Bio, Boston, MA). Cell viability was expressed as percentage of propidium iodide (PI; NanoEnTek, Inc., Newton, MA)-negative cells over the total cell number. Adherent and floating cells were analyzed for DNA fragmentation (apoptosis) by terminal deoxynucleotidyl transferase-mediated nick end labeling (TUNEL) assay (Roche, Mannheim, Germany) according to the manufacturer's recommendation. Fluorescence was measured by flow cytometry using a FACSort (Becton Dickinson, Franklin Lakes, NJ).

\section{Measurement of Growth Factors in Cell Supernatants}

MSCs were treated or not with IGF-1 for $24 \mathrm{~h}$ in serumfree conditions. Afterwards, medium was removed, and cells were washed twice with PBS and cultured in serum free conditions for further $24 \mathrm{~h}$ before collecting the supernatants. Supernatant levels of basic fibroblast growth factor (bFGF) and vascular endothelial growth factor (VEGF) were measured using a magnetic bead-based assay (BioPlex Pro cytokine assay, Mouse Group II; Bio-Rad, Hercules, CA, USA). Multianalyte profiling was performed by using Luminex xMAP technology on the Bioplex 200 Suspension Array System (Bio-Rad, Hercules, CA, USA). Analyses were performed according to the manufacturers' protocols, and data were processed with Bio-Plex Manager 5.0 software (Bio-Rad, Hercules, CA, USA). Data analysis was done with five-parametric-curve fitting.

Levels of IGF-1 and transforming growth factor- $\beta 1$ (TGF- $\beta 1$ ) were measured in the culture supernatant by using, respectively, the Mouse/Rat IGF-1 Quantikine ELISA Kit and the Second Generation Mouse/Rat/Porcine/ Canine TGF- $\beta 1$ Quantikine ELISA Kit (R\&D Systems, Inc., Minneapolis, MN, USA). Hepatocyte growth factor 
(HGF) was detected using the Mouse HGF ELISA Kit for cell culture supernatant (RayBiotech, Norcross, GA, USA). All samples were coded for a blinded analysis, and each sample concentration was determined in duplicate. The results were expressed in $\mathrm{pg} / \mathrm{ml} / 10^{5}$ cells.

\section{Statistical Analyses}

The results are expressed as means \pm SEM. Statistical analysis was performed using ANOVA followed by Tukey Cicchetti test for multiple comparisons or Bonferroni post hoc analysis. Statistical significance level was defined as $p<0.05$ or as indicated.

\section{RESULTS}

\section{IGF-1, GDNF, or TNF- $\alpha$ Induces Morphological Cytoskeletal Changes of MSCs}

Cellular migration requires morphological changes, wherein cells are structurally reorganized and cytoskeletal filaments adopt a well-ordered, parallel orientation $(22,37)$. Thus, we studied the effects of IGF-1, GDNF, or TNF- $\alpha$ on MSC cytoskeleton by analyzing the filamentous pattern and distribution of F-actin and vimentin. In normal conditions, a large number of cells showed an unpatterned orientation of cytoskeleton with filaments to be organized in independent directions. In the presence of IGF-1, GDNF, or TNF- $\alpha$, most of the cells displayed parallel-oriented filaments organized along the axis of the cells (Fig. 1). These structural changes in response to the above factors may be indicative of an architectural remodeling, contributory to the mechanical needs of migration.

\section{IGF-1, GDNF, or TNF- $\alpha$ Increase the Migration Capacity of MSCs}

In order to spot the most promigratory agents we used two different in vitro approaches. Firstly, we applied a scrape-healing assay where cells were scratched and MSC healing capacity was quantified (Fig. 2A, B). Results showed that treatment with IGF-1, GDNF, or TNF- $\alpha$ enhanced migration of the surrounding cells towards the injury, reducing the surface area of the scratch, which after 20 h was almost closed (Fig. 2A). In contrast, untreated
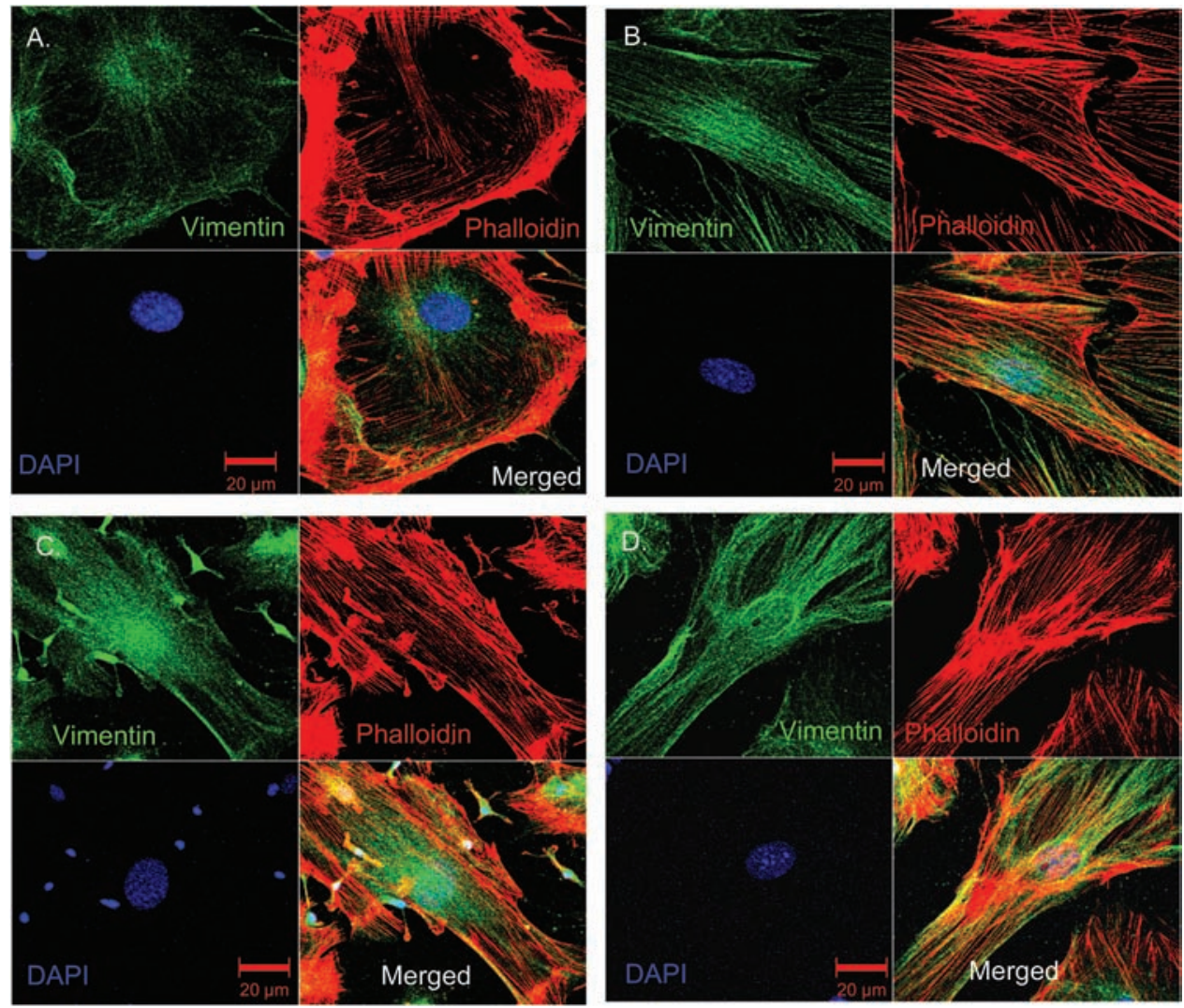

Figure 1. IGF-1, GDNF, and TNF- $\alpha$ treatment induces changes on MSC cytoskeletal proteins. Insulin-like growth factor-1 (IGF-1; $20 \mathrm{ng} / \mathrm{ml})$, glial cell-derived growth factor (GDNF) $(100 \mathrm{ng} / \mathrm{ml})$, and tumor necrosis factor (TNF)- $\alpha(100 \mathrm{ng} / \mathrm{ml})$ induce cytoskeletal rearrangements, shown by phalloidin staining (red) and immunocytochemical detection of vimentin (green). Representative images of mesenchymal stem cell (MSC) cytoskeletal organization under control conditions (A) or after incubation with IGF-1 (B), GDNF (C), and TNF- $\alpha$ (D). In untreated cells, filaments are organized in independent directions, while after the treatment they display a parallel orientation. 
A.
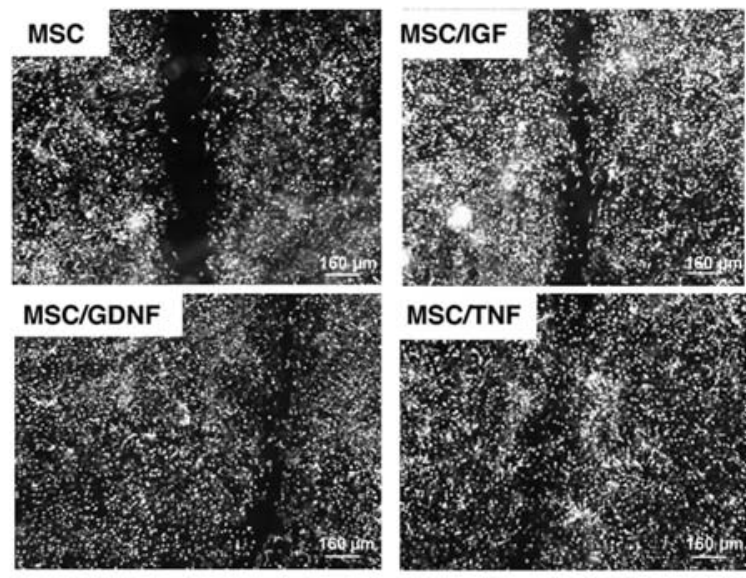

B.

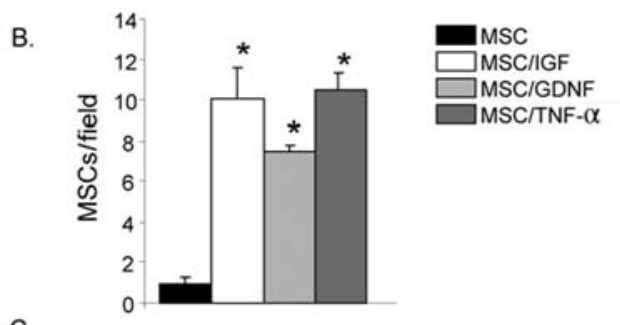

C.

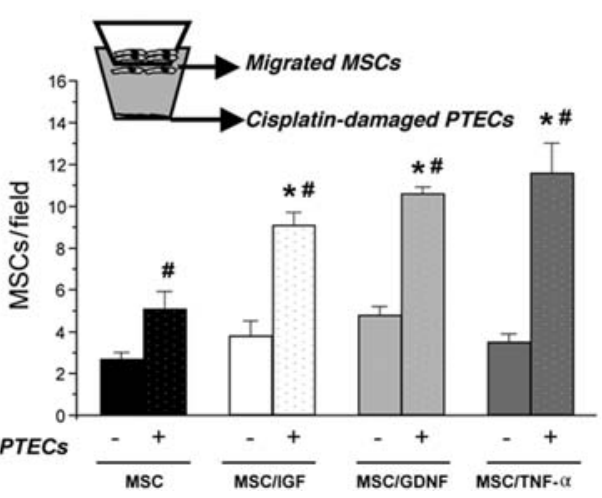

Figure 2. Preconditioning with IGF-1, GDNF, or TNF- $\alpha$ enhances MSC migration capacity. (A) Scrape-healing assay of MSCs under control conditions or after treatment with IGF-1 (20 ng/ml), GDNF (100 ng/ml), or TNF- $\alpha$ (100 ng/ml). After scratching, the surrounding cells migrated into the scraped zone. Representative images were taken $20 \mathrm{~h}$ after scratching. (B) Quantification of MSC healing capacity. Data are mean \pm SEM. $* p<0.05$ versus untreated MSCs. (C) Transmigration of untreated, IGF-, GDNF-, or TNF- $\alpha$-treated MSCs towards control or cisplatininjured PTECs. Data are mean \pm SEM. $* p<0.05$ versus untreated MSCs in coculture with cisPt/PTECs. $\# p<0.05$ versus the corresponding MSCs in coculture with control PTECs. PTECs, proximal tubular epithelial cells; CisPt, cisplatin.

MSCs displayed a low migratory activity in response to the injury and after $20 \mathrm{~h}$ scratch was still visible and distinct. To confirm that our results were due to MSC migration and not proliferation, we counted MSCs at the end of scrapehealing experiments and no differences were observed among the groups (MSC control: $2.45 \pm 0.09 \times 10^{4}, \mathrm{MSC} /$
IGF: $2.53 \pm 0.13 \times 10^{4}, \mathrm{MSC} / \mathrm{GDNF}: 2.45 \pm 0.05 \times 10^{4}, \mathrm{MSC} /$ TNF- $\alpha: 2.52 \pm 0.11 \times 10^{4}$ cells $\left./ \mathrm{cm}^{2}\right)(n=3)$.

Afterwards we applied an in vitro injury-migration model, based on a transwell system consisting of murine MSCs cocultured with cisplatin-injured proximal tubular epithelial cells (PTECs) (Fig. 2C). Migration of MSCs from the upper chamber across the membrane towards the cisplatin-damaged tubular cells was significantly higher than that observed when MSCs were in coculture with control PTECs (Fig. 2C). Preconditioning of MSCs with IGF-1, GDNF, or TNF- $\alpha$ amplified the migration response of the cells to cisplatin-injured PTECs as determined by a significant increase in the number of migrating cells found in the lower site of transfilter (Fig. 2C). Preconditioned cells that were cocultured with untreated PTECs did not exhibit significant migration activity (Fig. 2C).

\section{Preconditioning With IGF-1 Enhances MSC Engraftment In Vivo}

We studied whether MSC preconditioning with IGF-1, GDNF, or TNF- $\alpha$ before their in vivo infusion might influence MSC engraftment in damaged tissue of mice with acute kidney injury. Female C57BL6/J mice were injected with cisplatin, an antitumor drug whose clinical use is accompanied by high incidence of nephrotoxicity, associated with renal dysfunction and renal damage with extended structural alterations $(29,40)$. One day after cisplatin injection, mice were systemically infused with MSCs, and $24 \mathrm{~h}$ later cells were monitored in the injured kidney. Preconditioning of MSCs with IGF-1 before infusion significantly increased the migration of PKH26-labeled cells into the cisplatin-injured kidney $(34.8 \pm 3.8$ cells/100,000 renal cells), as compared to untreated MSCs (16.1 \pm 1.4

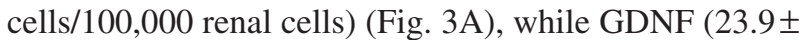
0.5 cells/100,000 renal cells) or TNF- $\alpha(18.1 \pm 2.4$ cells/ 100,000 renal cells) had lower or no effect on engraftment ability of MSCs. Engrafted cells in kidneys of mice with AKI were predominantly found in the peritubular areas (Fig. 3B) (60 $10 \%$ of total engrafted cells), and rarely in the context of tubular epithelium $(0.8 \pm 0.4 \%)$, while a number of $\mathrm{PKH} 26^{+}$cells were observed in glomeruli $(39.2 \pm$ $10 \%)$, which rapidly disappeared with time.

\section{Preconditioning With IGF-1 Enhances MSC-Mediated Protective Effect on Renal Structure and Function}

As IGF-1 preconditioning proved to be the most effective strategy for facilitating MSC engraftment in damaged tissue, we further examined the capacity of IGF-1-treated cells to restore renal structure and function after acute injury. Mice injected with cisplatin developed renal function impairment, characterized by high serum level of BUN, between days 4 and 7 after drug administration (29). Intravenous injection of $2 \times 10^{5} \mathrm{MSC}$ obtained from 

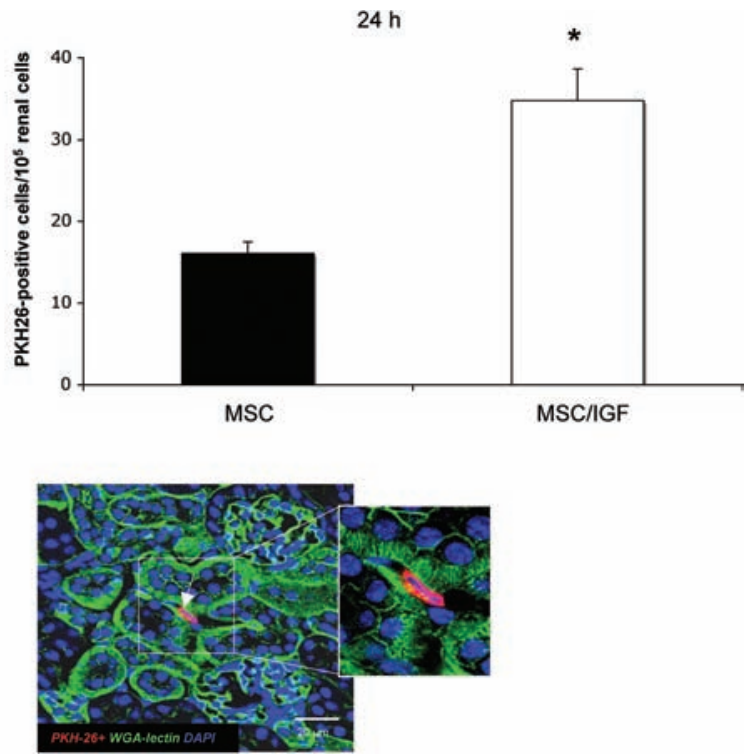

Figure 3. Effect of IGF-1 preconditioning on MSC engraftment in kidneys of cisplatin-treated mice after $24 \mathrm{~h}$. (A) Quantification of PKH26-labeled untreated (MSC) or IGF-1-treated (MSC/IGF) MSCs in cisplatin-injured renal tissue $24 \mathrm{~h}$ after injection. Data are mean \pm SEM. $* p<0.05$ versus MSCs. (B) PKH26-labeled cells (red fluorescence, arrows) were localized in the peritubular areas. Sections were stained with DAPI (nuclear staining, blue) followed by Wheat Germ Agglutinin (WGA) Lectin (green).

the $\mathrm{BM}$ of male mice into syngeneic female mice 1 day after cisplatin treatment protected mice from renal function deterioration, as shown by significantly lower BUN values $(65.52 \pm 14.9 \mathrm{mg} / \mathrm{dl})$ at 4 days, with respect to cisplatin-treated mice that received saline $(104.16 \pm 9.22$ $\mathrm{mg} / \mathrm{dl}$ ) (Fig. 4A). Injection of IGF-1-treated MSCs into cisplatin-injured mice resulted in a further BUN decrease $(29.9 \pm 6.42 \mathrm{mg} / \mathrm{dl}, p<0.05)$ as compared to both salinetreated and MSC-treated mice (Fig. 4A).

We next investigated whether renal function improvement was related to preservation of tubular structures. By light microscopy, normal kidneys showed no structural alterations, while the kidneys of cisplatin-treated mice given saline displayed significant tubular lesions at 4 days ( $p<0.05$ vs. normal), consisting of loss of brush border, flattening and loss of the tubular epithelium, nuclear fragmentation, and hyaline casts (Fig. 4B). Renal tissue of mice receiving untreated MSCs showed a significant reduction in cast formation and tubular necrosis in respect to saline-treated mice (Fig. 4B and Table 1). Remarkably, mice injected with IGF-1-treated MSCs showed further reduction in tubular necrosis and overall only minor ultrastructural tubular changes (Fig. 4B and Table. 1).

Concomitantly, the presence of IGF-1-treated MSCs at 4 days was still higher in the injured kidney (4.2-fold, $p<0.05$ ) than untreated MSCs (Fig. 4C). Furthermore, between 1 and 4 days a dramatic decline in the number of engrafted cells occurred, wherein only $6.8 \%$ of the initial number of untreated cells was still present in renal tissue. In contrast, the percentage of remaining IGF-1-treated cells in the same time course was $13.0 \%$ of the initial number, which may imply a possible prosurvival effect of IGF-1 on exogenously infused MSCs. No PKH26+ cells were detected in heart, lungs and brain, while few cells were found in the liver $\left(2.4 \pm 0.7 \mathrm{PKH}-26^{+}\right.$cells/100,000 liver cells).

\section{IGF-1 Improves MSC Survival In Vitro and Stimulates IGF-1 Production}

To examine whether IGF-1 exerts prosurvival effects on MSCs, we cultured cells preconditioned with IGF-1 or not, at the presence of $\mathrm{H}_{2} \mathrm{O}_{2}(200 \mu \mathrm{M}, 24 \mathrm{~h})$ (Fig 5A). Our results showed that $\mathrm{H}_{2} \mathrm{O}_{2}$ significantly reduced MSC viability in respect to untreated cells $(20.0 \pm 2.2 \%$ vs. $97.5 \pm 0.3 \%$, $p<0.05$ ), while IGF-1 treatment significantly limited MSC susceptibility to $\mathrm{H}_{2} \mathrm{O}_{2}(64.9 \pm 0.5 \%$ vs. $20.0 \pm 2.2 \%, p<0.05)$. Under the same conditions apoptosis of MSCs was dramatically reduced in IGF-1-treated cultures (Fig. 5B).

Since it has been previously documented $(16,41,43)$ that MSCs exert their beneficial effects via paracrine production of antiapoptotic, mitogenic, and vasculotrophic factors, we investigated the effect of IGF-1 on MSC ability to produce IGF-1, TGF- $\beta 1$, HGF, bFGF, VEGF by multianalyte profiling assay. Our results showed that MSCs constitutively release considerable amounts of IGF-1, TGF- $\beta 1$, HGF, bFGF, and VEGF (470.25 \pm 51.09 , $42.30 \pm 3.51,576.57 \pm 88.95,100.66 \pm 23.68$, and $2,293.04 \pm$ $64.00 \mathrm{pg} / \mathrm{ml} / 10^{5}$ cells, respectively). When MSCs were exposed to IGF-1 a 10-fold increase $(4,302.07 \pm 21.58 \mathrm{pg} /$ $\mathrm{ml} / 10^{5}$ cells) in the production of IGF-1 was observed (Fig. 5C).

\section{IGF-1 Induces Changes in CXCR4 Cellular Expression}

In order to investigate the mechanisms underlying the enhanced renal migration and protective effect of MSCs preconditioned with IGF-1, we focused on CXCR4 that plays a pivotal role in the migration and engraftment of BM-MSCs $(6,12,35)$. Therefore, we examined the surface expression of CXCR4 in response to IGF-1 by FACS (Fig. 6A and Table 2). Results showed that IGF-1 treatment induced a twofold increase of CXCR4 expression on MSC surface (Table 2). At variance, GDNF (3.2\%) and TNF- $\alpha(3.5 \%)$ do not exhibit any significant increase on CXRC4 surface expression as compared to corresponding MSC controls (2.5\% and 2.6\%, respectively).

Consistently, evaluation of CXCR4 in MSCs by a computer-based image analysis system showed a significant increase in the intracellular granular staining of CXCR4 in IGF-1-treated cells (twofold, $p<0.05$ ), in comparison to untreated cells (Fig. 6B). Furthermore, 
A.

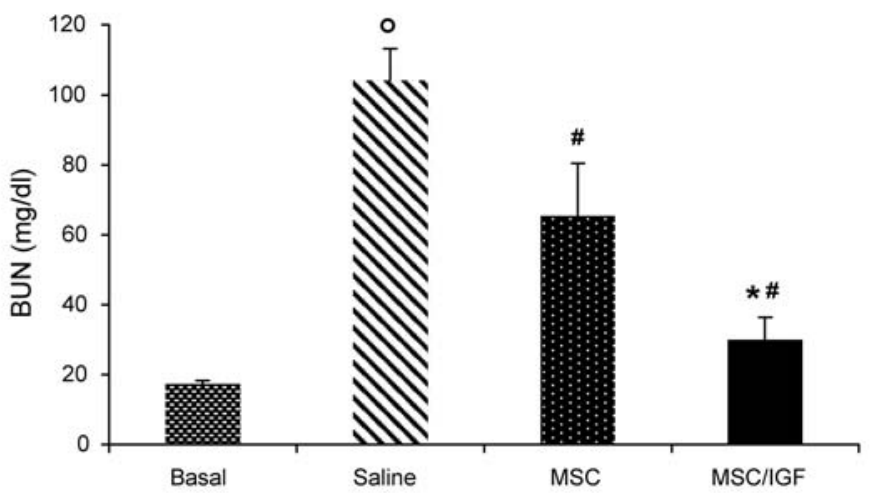

B.

cisPt + saline

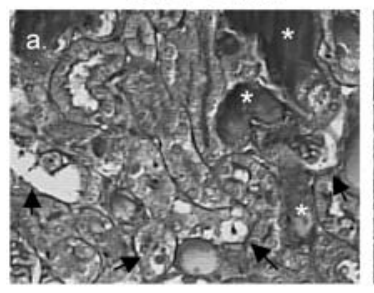

cisPt + MSC

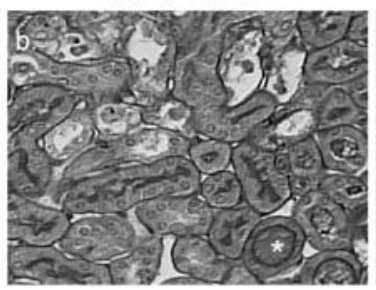

cisPt + MSC/IGF

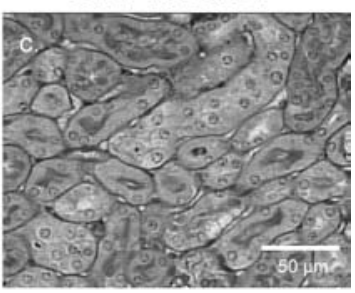

C.

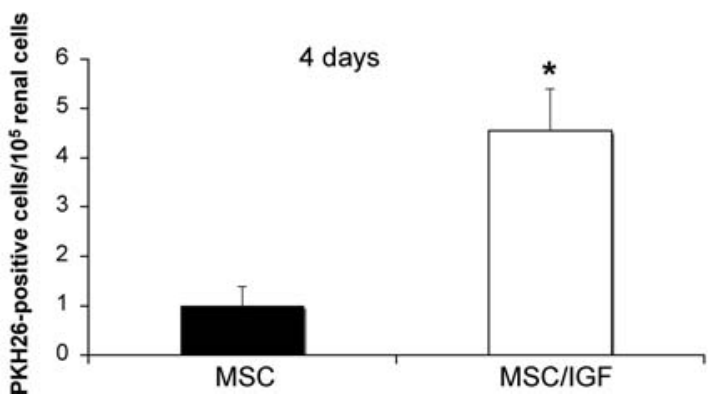

Figure 4. IGF-1-treated MSCs exert a strong renal protective effect on mice with cisplatin-induced acute kidney injury (AKI). (A) Blood urea nitrogen (BUN) was evaluated before (basal) and 4 days after cisplatin treatment in mice that received an intravenous injection (IV) of saline, unstimulated MSCs $\left(2 \times 10^{5}\right.$ cells) or IGF-1-treated MSCs (MSC/IGF, $2 \times 10^{5}$ cells). Data are means \pm SEM. ${ }^{*} p<0.05$ versus MSCs, $\# p<0.05$ versus basal, $\# p<0.05$ versus saline. (B) Histological examination of kidney sections of C57BL6/J cisplatin-treated mice, given (IV) saline, MSCs, or IGF-1-treated MSCs at 4 days. Representative images of the kidney of cisplatintreated mouse receiving saline showing tubular epithelial cell degeneration and necrosis (arrows) and cast formation $(*)$. Treatment with MSCs resulted in less severe tubular damage with occasional luminal casts. Tubular lesions in cisplatin mice receiving IGF-1preconditioned MSCs were almost absent. (C) Quantification of engrafted PKH26-positive MSCs in cisplatin-injured renal tissue at 4 days. Data are means \pm SEM. $* p<0.05$ versus MSCs.

Table 1. Effects of MSCs on Renal Histology at 4 Days

\begin{tabular}{|c|c|c|}
\hline Group & Casts ( $n / \mathrm{HPF})$ & Tubular Necrosis (n/HPF) \\
\hline Cisplatin + saline & $6.11 \pm 0.81$ & $3.72 \pm 0.42$ \\
\hline Cisplatin + MSC & $1.71 \pm 0.53^{\circ \circ}$ & $1.75 \pm 0.50^{\circ}$ \\
\hline Cisplatin + MSC/IGF & $0.15 \pm 0.11^{\circ \circ}$ & $0.18 \pm 0.07^{\circ \circ} \#$ \\
\hline
\end{tabular}

Quantification of casts and necrotic tubuli, as numbers per high-power field (HPF), in cisplatin-treated mice at 4 days receiving saline, mesenchymal stem cells (MSCs), or insulin-like growth factor-1 (IGF-1)-treated MSCs. Normal kidneys exhibited no structural alterations. Data are mean scores \pm SEM. ${ }^{\circ} p<0.001,{ }^{\circ} p<0.005$ versus saline, $\# p<0.05$ versus MSC.
Western blotting experiments showed that IGF-1 stimulates the expression of total CXCR4 (Fig. 6C).

To define the biological significance of IGF-1-mediated CXCR4 upregulation, we performed scrape-healing experiments in the presence of a neutralizing antibody. The functional blocking of CXCR 4 totally abrogated the promigratory effect of IGF-1 on MSCs (Fig. 7A). Additionally, motility parameters as total distance (Fig. 7B), straight distance (Fig. 7C), and velocity (Fig. 7D), which were significantly increased in cells exposed to IGF-1, normalized back to 


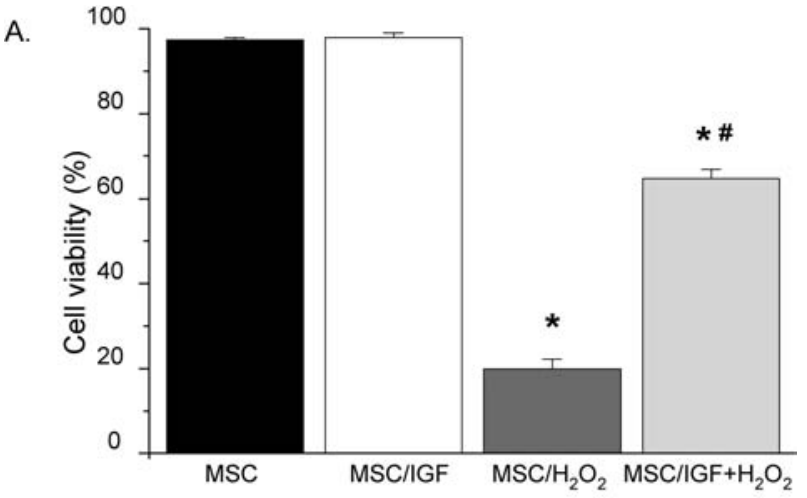

B.
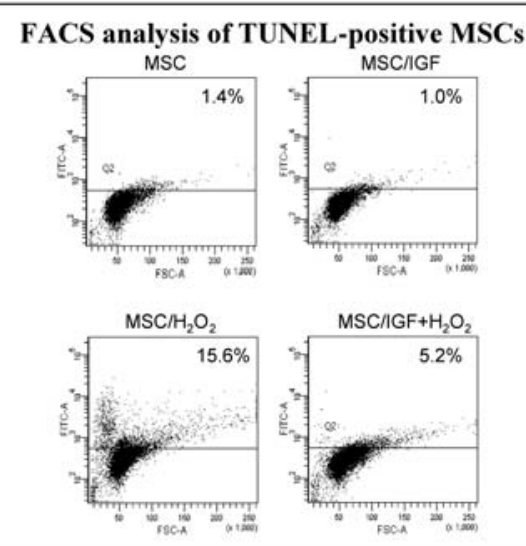

C.

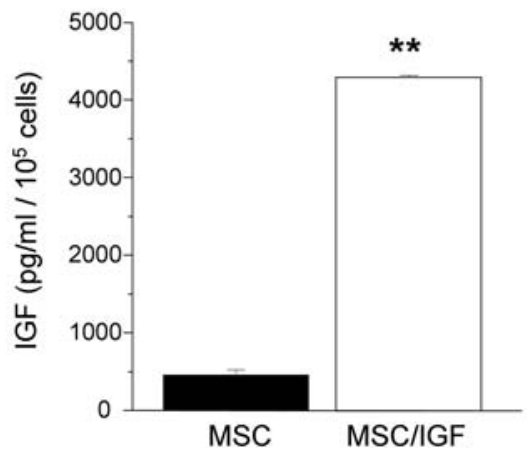

Figure 5. IGF-1 improves MSC survival in vitro and stimulates IGF-1 production. (A) MSCs were exposed to medium alone (MSC), IGF-1 (MSC/IGF), $\mathrm{H}_{2} \mathrm{O}_{2}\left(\mathrm{MSC} / \mathrm{H}_{2} \mathrm{O}_{2}\right)$, or IGF-1 and $\mathrm{H}_{2} \mathrm{O}_{2}$ (MSC/IGF $\left.+\mathrm{H}_{2} \mathrm{O}_{2}\right)$. IGF-1 treatment significantly reduced MSC susceptibility to $\mathrm{H}_{2} \mathrm{O}_{2}$. Results are the mean \pm SEM of five independent experiments. ${ }^{*} p<0.05$ versus MSC and MSC/ IGF; $\# p<0.05$ versus $\mathrm{MSC} / \mathrm{H}_{2} \mathrm{O}_{2}$. (B) Representative graphs of the percentage of terminal deoxynucleotidyl transferase dUTP nick end labeling (TUNEL)-positive MSCs (upper quadrant) analyzed by fluorescence-activated cell sorting (FACS). IGF-1 dramatically limited apoptotic death of MSCs exposed to $\mathrm{H}_{2} \mathrm{O}_{2}$. One of two representative experiments is shown. (C) Incubation of MSCs with IGF-1 showed a marked increase in IGF-1 secretion as compared to control cells (MSC). Results are the mean \pm SEM of four independent experiments. $* * p<0.000005$ versus MSC. control values by CXCR4 antibody, indicating a key role for CXCR4 on IGF-1-induced migration.

\section{DISCUSSION}

Presently, the delivery of MSCs via systemic infusion is the predominant route being used in the majority of the trials since local transplantation not only is it highly invasive but also seems to involve excessive cell death early after local administration, mainly due to lack of nutrients and oxygen (32). However, with evidence for massive entrapment of stem cells in the lungs and in capillary beds of different tissues, the need of developing new strategies to enhance cell homing to target tissues emerges as a prerequisite for the success of MSCbased systemic therapies. Here we documented a novel approach to optimize MSC engraftment efficiency and increase their therapeutic effects, based on a preconditioning with IGF-1 before systemic infusion. The most promigratory compounds were initially chosen through an in vitro injury-migration model consisting of MSCs and cisplatin-damaged tubular cells and by applying a scrape-healing setting. From our in vitro studies, we have found that preconditioning of MSCs by IGF-1, GDNF, or TNF- $\alpha$ induced a marked cytoskeletal rearrangement, enhanced migration towards injured tubular cells, and accelerated migration in the scrape-healing assay. In vivo, however, IGF-1 showed higher ability to improve MSC engraftment in the cisplatin-injured kidney. Preconditioning with IGF-1 also resulted in remarkable amplification of the protective effect of MSCs to such an extent that BUN values were comparable to the normal values obtained from healthy animals. Similarly to the effect on renal function, MSCs treated with IGF-1 completely abrogated renal structure damage, implying a coordinated functional and structural protective effect of preconditioned cells in cisplatin-induced AKI.

Several studies have proposed the axis stromal cell derived factor (SDF-1)/CXCR4 as a pivotal mediator of migration and engraftment of MSCs $(6,12,35)$. Here, we observed that CXCR4 was constitutively expressed at the cell membrane and upregulated by IGF-1 treatment. Interestingly, IGF-1 induced a twofold increase, both in the number of cells expressing CXCR4 and in the number of engrafted cells, indicating a correlation between CXCR4 surface expression and engraftment. Furthermore, evaluation of the intracellular storage and total CXCR4 in IGFtreated cells showed a significant increase in respect to untreated cells. The functional role of CXCR4 upregulation in response to IGF-1 was documented by CXCR4 blocking which totally abrogated the promigratory effect of IGF-1 on MSCs and affected crucial motility parameters as distance and velocity. These findings indicate that CXCR4 plays a key role in migration of IGF-1-treated MSCs in vitro and could well explain the increased 
A.
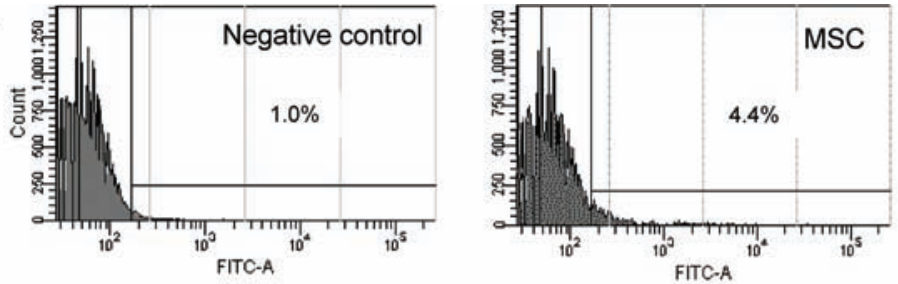

B.

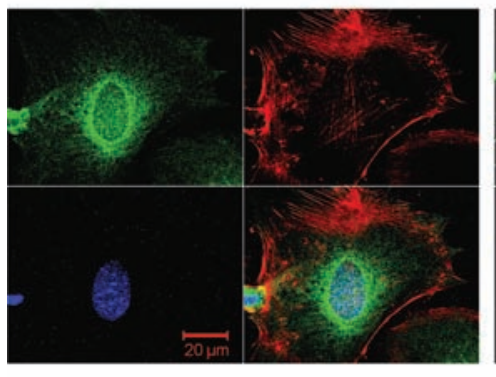

MSC

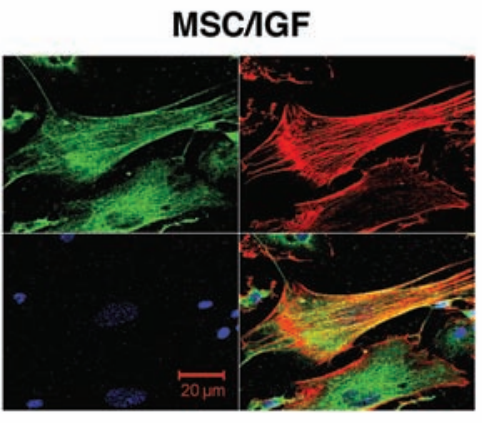

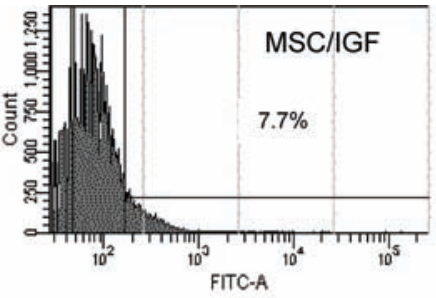

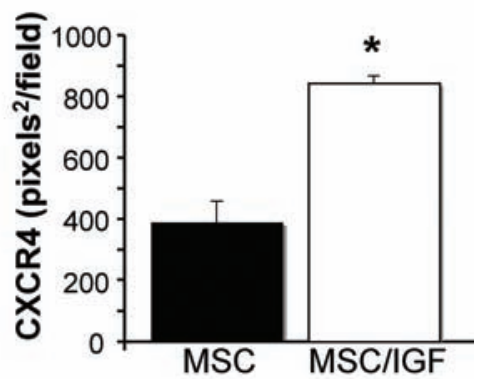

C.

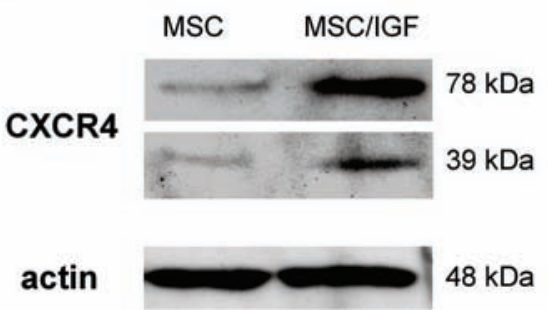

Figure 6. IGF-1 preconditioning of MSCs increases CXCR4 expression. (A) Representative fluorescence histograms showing the C-X-C chemokine receptor type 4 (CXCR4) expression in untreated and IGF-1-treated MSCs by FACS. (B) Representative immunofluorescence images of intracellular CXCR4 (green) expression and F-actin (red) in untreated MSCs (left) or treated with IGF-1 (20 ng/ml) for $24 \mathrm{~h}$ (central). Quantification of intracellular CXCR4 in untreated or IGF-1-treated MSCs using a computer based image analysis system (right). Data are mean \pm SEM. ${ }^{*} p<0.05$ versus untreated MSCs. (C) Western blot analysis of CXCR4 expression in MSCs treated or not with IGF-1 for $24 \mathrm{~h}$. Two bands were recognized at about $39 \mathrm{kDa}$ (monomer) and $78 \mathrm{kDa}$ (dimer). Control loading is shown by actin.

engraftment of these cells in vivo. In support of this hypothesis, we also detected an augmented expression of SDF-1, the ligand of CXCR4, in renal damaged tissue of cisplatin mice (data not shown).

Although we observed only a small increase in the percentage of the cells expressing surface CXCR4, this difference was of biological significance and able to affect migration capacity of MSCs, consistent with previous studies showing that a slight increase in the percentage CXCR4-expressing MSCs induced by short-term

Table 2. Expression of CXCR4 by FACS Analysis

\begin{tabular}{lc}
\hline & Fluorescence Intensity (\%) \\
\hline MSC & $3.0 \pm 0.5$ \\
MSC/IGF & $5.9 \pm 0.6 \#$ \\
\hline
\end{tabular}

Data are mean \pm SEM of five independent experiments. CXCR4, C-X-C chemokine receptor type 4; FACS, fluorescence activated cell sorting. $\# p<0.05$ versus MSC. hypoxia resulted in significant improvement of migration capacity (15). On the other hand, the increased intracellular expression of CXCR4 might serve as a receptor reservoir $(19,48)$, which can be potentially induced to cell surface in response to IGF-1 stimulation. Unlike IGF-1, GDNF and TNF- $\alpha$ did not exhibit any effect on CXCR4 expression. This difference in CXCR4 expression between IGF-1 preconditioning and the other factors can well justify the fact that only IGF-1 displayed significant effects on MSC engraftment into the injured tissue.

Previous studies showed that MSC exert beneficial effects on tubular cell repair in acute kidney injury by producing the mitogenic and prosurvival factor IGF-1. Knocking down IGF-1 expression in MSCs decreased tubular cell proliferation, increased apoptosis, and limited their protective effect on renal function (16). Here we documented that IGF-1 preconditioning strongly enhanced the reno-protective potential of infused MSCs, as well 
A.

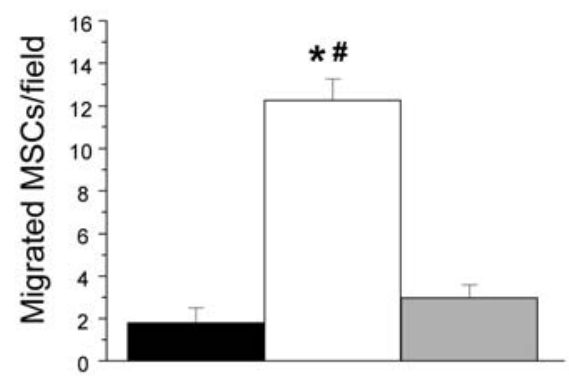

C.

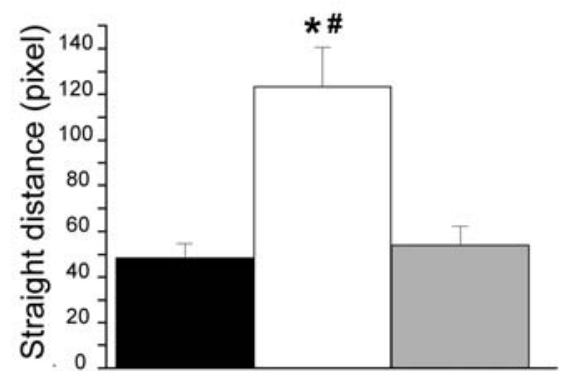

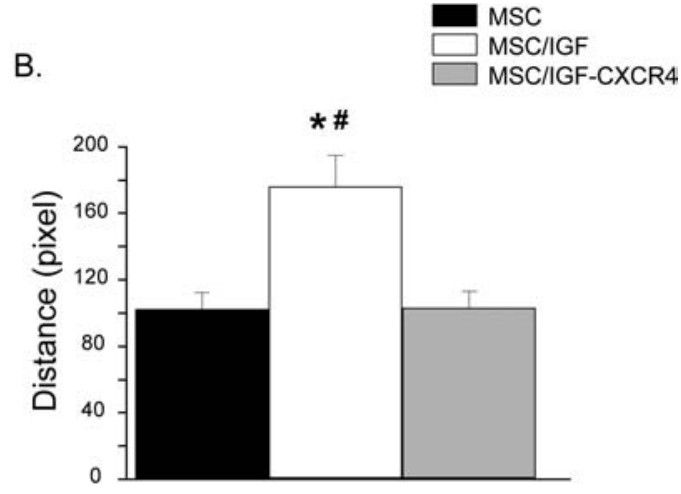

D.

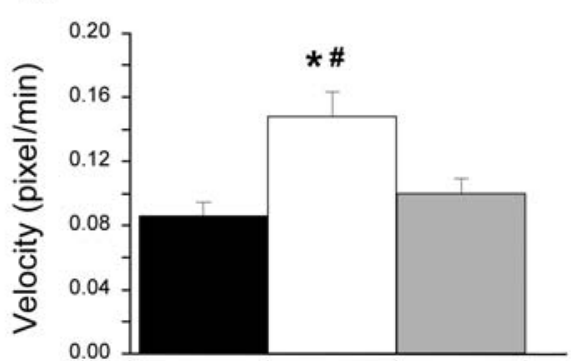

Figure 7. Role of CXCR4 in IGF-1 promigratory effects on MSCs. (A) Quantification of cell migration in untreated MSCs (black) or treated with IGF-1 (white) or IGF-1 plus anti-CXCR4 neutralizing antibody (gray) $20 \mathrm{~h}$ after scratching. (B-D) Analysis of different parameters of MSC motility $20 \mathrm{~h}$ after scratching in untreated MSCs (black) or treated with IGF-1 (white) or IGF-1 plus anti-CXCR4 neutralizing antibody (gray). (B) Distance, (C) straight distance, and (D) velocity. Data are mean \pm SEM of two independent experiments. ${ }^{*} p<0.05$ versus untreated MSCs, $\# p<0.05$ versus MSCs treated with IGF-1 plus CXCR4 Ab.

as induced a dramatic secretion of IGF-1, suggesting that IGF-1-treated MSCs exert their regenerative effects on tubular damage by means of an excessive release of IGF-1 at the sites of the injury.

The relative paucity of MSCs in the renal tissue in the face of their remarkable protective effects observed herein is consistent with previous findings in animals with AKI, showing that injected MSCs, transiently localized at early time points, in peritubular areas, and disappeared after $24-72 \mathrm{~h}$ in ischemic rat kidney (41). The frequency of IGF-1-preconditioned cells however was increased in the injured kidney at 1 day and still remained higher at 4 day as compared to untreated MSCs. The fact that IGF-1 preconditioning delays the rate of decline of engrafted cells suggests a beneficial effect of IGF-1 not only on the migration potentials of these cells but also on their longevity in the target damaged tissue. This delay in depletion of IGF-1-treated cells from injured kidney might be due to prosurvival signaling stimulated by IGF-1. Consistently, in vitro experiments showed that IGF-1-treated MSCs were less sensitive to the oxidative damage induced by $\mathrm{H}_{2} \mathrm{O}_{2}$. Altogether these data potentially suggest that IGF-1 improves the resistance of MSCs against the proapoptotic microenvironment of the injured renal tissue.
The therapeutic impact and feasibility of the current approach was evaluated by using a murine cisplatininduced AKI model, not only as it is a well-defined and highly reproducible model (29-31) but also because the wide use of cisplatin as a chemotherapeutic agent potentially renders the current approach remarkably constructive and therapeutically relevant. In fact, a relevant clinical trial using ex vivo expanded third party mesenchymal stem cells to repair renal function in cisplatin-induced $\mathrm{AKI}$ in patients with solid organ cancers is already approved by regulatory authorities. Considering the beneficial effect of MSCs in cisplatin-induced AKI, we chose to use a relatively high dose of cisplatin, in order to bring forth the effect of IGF-1 preconditioning. Interestingly, even with an uncommonly high dose of cisplatin, which was able to induce severe functional and structural renal alterations, IGF-1-treated MSCs were highly protective and capable to abrogate almost completely the detrimental effects of cisplatin.

In comparison with other strategies aiming to improve efficacy of stem cells, in particular genetic modification, ex vivo preconditioning with IGF-1 presents diverse advantages in terms of clinical feasibility. First, IGF-1 can be administered to MSCs with negligible in vitro manipulations, avoiding extended passaging and persisting 
incubations, which may interfere with cell quality. Second, IGF-1 can be entirely removed before injection without loss of its beneficial properties, rendering the risk of side effects particularly unlikely.

Here, we report a "multum in parvo" therapeutic approach, which amplifies the beneficial effect of MSCs in tissue injury, through an effortless preconditioning with IGF-1. Our results showed that preconditioning of MSCs with IGF-1 before infusion improves their migration capacity and restores normal renal function after AKI. These data represent a new therapeutic paradigm, suggesting that improving MSC migration ability could increase therapeutically relevant effects. The enhanced delivery to specific tissues could increase the efficiency of cell therapy and reduce the number of infused cells, potentially limiting the complications and the cost of developing a therapeutic product. In as much as MSCs are already used safely in clinical studies, it is plausible that this novel therapeutic paradigm may be implemented rapidly in the clinical setting or facilitates the development of novel cell-based therapies for various diseases and damages.

ACKNOWLEDGMENTS: We thank Daniela Corna, Cinzia Rota, Daniela Rottoli, Lorena Longaretti, and Chiara Ardeleani for excellent technical assistance. We also thank Leda Vassilopoullou and Joanna Johnson for manuscript corrections. This study was supported by Research Training Network "Developing a stem cell based therapy to replace nephrons lost through reflux nephropathy" (http://www.kidstem.org) funded by the European Community as part of the Framework program 6 (FP6 036097-2) and by Juvenile Diabetes Research Foundation $(J D R F)$ International. Part of the research leading to these results has also received funding from the European Community under the European Community's Seventh Framework Programme (FP7/2007-2013), grant number 223007, STAR-TREK project. Valentina Benedetti is recipient of a fellowship from "Fondazione Aiuti per la Ricerca sulle Malattie Rare” (ARMR), Bergamo, Italy. The authors declare no potential conflicts of interest.

\section{REFERENCES}

1. Abe, H.; Ina, K.; Kitamura, H.; Sumiyoshi, H.; Tatsukawa, S.; Yoshioka, H.; Fujikura, Y. Role of the CXCL12/CXCR4 axis in milky spots of rats bearing ascitic-type hepatoma. Anat. Sci. Int. 84:226-236; 2009.

2. Anjos-Afonso, F.; Siapati, E. K.; Bonnet, D. In vivo contribution of murine mesenchymal stem cells into multiple cell-types under minimal damage conditions. J. Cell Sci. 117:5655-5664; 2004.

3. Ankrum, J.; Karp, J. M. Mesenchymal stem cell therapy: Two steps forward, one step back. Trends Mol. Med. 16: 203-209; 2010.

4. Assis, A. C.; Carvalho, J. L.; Jacoby, B. A.; Ferreira, R. L.; Castanheira, P.; Diniz, S. O.; Cardoso, V. N.; Goes, A. M.; Ferreira, A. J. Time-dependent migration of systemically delivered bone marrow mesenchymal stem cells to the infarcted heart. Cell Transplant. 19:219-230; 2010.

5. Brenner, S.; Whiting-Theobald, N.; Kawai, T.; Linton, G. F.; Rudikoff, A. G.; Choi, U.; Ryser, M. F.; Murphy, P. M.; Sechler, J. M.; Malech, H. L. CXCR4-transgene expression significantly improves marrow engraftment of cultured hematopoietic stem cells. Stem Cells 22:1128$1133 ; 2004$.

6. Chamberlain, G.; Wright, K.; Rot, A.; Ashton, B.; Middleton, J. Murine mesenchymal stem cells exhibit a restricted repertoire of functional chemokine receptors: Comparison with human. PLoS One 3:e2934; 2008.

7. Chen, S. L.; Fang, W. W.; Ye, F.; Liu, Y. H.; Qian, J.; Shan, S. J.; Zhang, J. J.; Chunhua, R. Z.; Liao, L. M.; Lin, S.; Sun, J. P. Effect on left ventricular function of intracoronary transplantation of autologous bone marrow mesenchymal stem cell in patients with acute myocardial infarction. Am. J. Cardiol. 94:92-95; 2004.

8. Cheng, Z. O., L.; Zhou, X.; Li, F.; Jia, X.; Zhang, Y.; Liu, X.; Li, Y.; Ward, C. A.; Melo, L. G.; Kong, D. Targeted migration of mesenchymal stem cells modified with CXCR4 gene to infarcted myocardium improves cardiac performance. Mol. Ther. 16:571-579; 2008.

9. Gooch, A.; Doty, J.; Flores, J.; Swenson, L.; Toegel, F. E.; Reiss, G. R.; Lange, C.; Zander, A. R.; Hu, Z.; Poole, S.; Zhang, P.; Westenfelder, C. Initial report on a phase I clinical trial: Prevention and treatment of postoperative acute kidney injury with allogeneic mesenchymal stem cells in patients who require on-pump cardiac surgery. Cell. Ther. Transplant. 1:31-35; 2008.

10. Hagiwara, M.; Shen, B.; Chao, L.; Chao, J. Kallikreinmodified mesenchymal stem cell implantation provides enhanced protection against acute ischemic kidney injury by inhibiting apoptosis and inflammation. Hum. Gene Ther. 19:807-819; 2008.

11. Hare, J. M.; Traverse, J. H.; Henry, T. D.; Dib, N.; Strumpf, R. K.; Schulman, S. P.; Gerstenblith, G.; DeMaria, A. N.; Denktas, A. E.; Gammon, R. S.; Hermiller, J. B. J.; Reisman, M. A.; Schaer, G. L.; Sherman, W. A randomized, double-blind, placebo-controlled, dose-escalation study of intravenous adult human mesenchymal stem cells (prochymal) after acute myocardial infarction. J. Am. Coll. Cardiol. 54:2277-2286; 2009.

12. Honczarenko, M.; Le, Y.; Swierkowski, M.; Ghiran, I.; Glodek, A. M.; Silberstein, L. E. Human bone marrow stromal cells express a distinct set of biologically functional chemokine receptors. Stem Cells 24:1030-1041; 2006.

13. Horwitz, E. M.; Gordon, P. L.; Koo, W. K.; Marx, J. C.; Neel, M. D.; McNall, R. Y.; Muul, L.; Hofmann, T. Isolated allogeneic bone marrow-derived mesenchymal cells engraft and stimulate growth in children with osteogenesis imperfecta: Implications for cell therapy of bone. Proc. Natl. Acad. Sci. USA 99:8932-8937; 2002.

14. Hung, S. C.; Pochampally, R. R.; Chen, S. C.; Hsu, S. C.; Prockop, D. J. Angiogenic effects of human multipotent stromal cell conditioned medium activate the PI3K-Akt pathway in hypoxic endothelial cells to inhibit apoptosis, increase survival, and stimulate angiogenesis. Stem Cells 25:2363-2370; 2007.

15. Hung, S. C.; Pochampally, R. R.; Hsu, S. C.; Sanchez, C.; Chen, S. C.; Spees, J.; Prockop, D. J. Short-term exposure of multipotent stromal cells to low oxygen increases their expression of CX3CR 1 and CXCR4 and their engraftment in vivo. PLoS One 2:e416; 2007.

16. Imberti, B.; Morigi, M.; Tomasoni, S.; Rota, C.; Corna, D.; Longaretti, L.; Rottoli, D.; Valsecchi, F.; Benigni, A.; Wang, J.; Abbate, M.; Zoja, C.; Remuzzi, G. Insulin-like growth factor-1 sustains stem cell mediated renal repair. J. Am. Soc. Nephrol. 18:2921-2928; 2007. 
17. Karp, J. M.; Leng Teo, G. S. Mesenchymal stem cell homing: The devil is in the details. Cell Stem Cell 4:206-216; 2009.

18. Koc, O. N.; Day, J.; Nieder, M.; Gerson, S. L.; Lazarus, H. M.; Krivit, W. Allogeneic mesenchymal stem cell infusion for treatment of metachromatic leukodystrophy (MLD) and Hurler syndrome (MPS-IH). Bone Marrow Transplant. 30:215-222; 2002.

19. Kollet, O.; Petit, I.; Kahn, J.; Samira, S.; Dar, A.; Peled, A.; Deutsch, V.; Gunetti, M.; Piacibello, W.; Nagler, A.; Lapidot, T. Human CD34(+) CXCR4(-) sorted cells harbor intracellular CXCR4, which can be functionally expressed and provide NOD/SCID repopulation. Blood 100:27782786; 2002.

20. Kraitchman, D. L.; Tatsumi, M.; Gilson, W. D.; Ishimori, T.; Kedziorek, D.; Walczak, P.; Segars, W. P.; Chen, H. H.; Fritzges, D.; Izbudak, I.; Young, R. G.; Marcelino, M.; Pittenger, M. F.; Solaiyappan, M.; Boston, R. C.; Tsui, B. M.; Wahl, R. L.; Bulte, J. W. Dynamic imaging of allogeneic mesenchymal stem cells trafficking to myocardial infarction. Circulation 112:1451-1461; 2005.

21. Kumar, S.; Ponnazhagan, S. Bone homing of mesenchymal stem cells by ectopic alpha 4 integrin expression. FASEB J. 21:3917-3927; 2007.

22. Lauffenburger, D. A.; Horwitz, A. F. Cell migration: A physically integrated molecular process. Cell 84:359-369; 1996.

23. Le Blanc, K.; Frassoni, F.; Ball, L.; Locatelli, F.; Roelofs, H.; Lewis, I.; Lanino, E.; Sundberg, B.; Bernardo, M. E.; Remberger, M.; Dini, G.; Egeler, R. M.; Bacigalupo, A.; Fibbe, W.; Ringden, O. Mesenchymal stem cells for treatment of steroid-resistant, severe, acute graft-versus-host disease: A phase II study. Lancet 371:1579-1586; 2008.

24. Le Blanc, K.; Rasmusson, I.; Sundberg, B.; Gotherstrom, C.; Hassan, M.; Uzunel, M.; Ringden, O. Treatment of severe acute graft-versus-host disease with third party haploidentical mesenchymal stem cells. Lancet 363:1439-1441; 2004.

25. Li, Y.; Yu, X.; Lin, S.; Li, X.; Zhang, S.; Song, Y. H. Insulin-like growth factor 1 enhances the migratory capacity of mesenchymal stem cells. Biochem. Biophys. Res. Commun. 356:780-784; 2007.

26. Majumdar, M. K.; Thiede, M. A.; Haynesworth, S. E.; Bruder, S. P.; Gerson, S. L. Human marrow-derived mesenchymal stem cells (MSCs) express hematopoietic cytokines and support long-term hematopoiesis when differentiated toward stromal and osteogenic lineages. J. Hematother. Stem Cell Res. 9:841-848; 2000.

27. Meyer, G. P.; Wollert, K. C.; Lotz, J.; Steffens, J.; Lippolt, P.; Fichtner, S.; Hecker, H.; Schaefer, A.; Arseniev, L.; Hertenstein, B.; Ganser, A.; Drexler, H. Intracoronary bone marrow cell transfer after myocardial infarction: Eighteen months' follow-up data from the randomized, controlled BOOST (BOne marrOw transfer to enhance ST-elevation infarct regeneration) trial. Circulation 113:1287-1294; 2006.

28. Mills, C. Osiris therapeutics announces preliminary results for prochymal phase III GvHD trials. Press Release; 2009. [cited 1 November, 2009]; available from: http://investor. osiris.com/releasedetail.cfm?ReleaseID $=407404$.

29. Morigi, M.; Imberti, B.; Zoja, C.; Corna, D.; Tomasoni, S.; Abbate, M.; Rottoli, D.; Angioletti, S.; Benigni, A.; Perico, N.; Alison, M.; Remuzzi, G. Mesenchymal stem cells are renotropic, helping to repair the kidney and improve function in acute renal failure. J. Am. Soc. Nephrol. 15:1794-1804; 2004.

30. Morigi, M.; Introna, M.; Imberti, B.; Corna, D.; Abbate, M.; Rota, C.; Rottoli, D.; Benigni, A.; Perico, N.; Zoja,
C.; Rambaldi, A.; Remuzzi, A.; Remuzzi, G. Human bone marrow mesenchymal stem cells accelerate recovery of acute renal injury and prolong survival in mice. Stem Cells 26:2075-2082; 2008.

31. Morigi, M.; Rota, C.; Montemurro, T.; Montelatici, E.; Lo Cicero, V.; Imberti, B.; Abbate, M.; Zoja, C.; Cassis, P.; Longaretti, L.; Rebulla, P.; Introna, M.; Capelli, C.; Benigni, A.; Remuzzi, G.; Lazzari, L. Life-sparing effect of human cord blood-mesenchymal stem cells in experimental acute kidney injury. Stem Cells 28:513-522; 2010.

32. Muschler, G. F.; Nakamoto, C.; Griffith, L. G. Engineering principles of clinical cell-based tissue engineering. J. Bone Joint Surg. Am. 86-A:1541-1558; 2004.

33. Phinney, D. G.; Prockop, D. J. Concise review: Mesenchymal stem/multipotent stromal cells: The state of transdifferentiation and modes of tissue repair-current views. Stem Cells 25:2896-2902; 2007.

34. Pittenger, M. F.; Mackay, A. M.; Beck, S. C.; Jaiswal, R. K.; Douglas, R.; Mosca, J. D.; Moorman, M. A.; Simonetti, D. W.; Craig, S.; Marshak, D. R. Multilineage potential of adult human mesenchymal stem cells. Science 284:143-147; 1999.

35. Ponte, A. L.; Marais, E.; Gallay, N.; Langonne, A.; Delorme, B.; Herault, O.; Charbord, P.; Domenech, J. The in vitro migration capacity of human bone marrow mesenchymal stem cells: Comparison of chemokine and growth factor chemotactic activities. Stem Cells 25:1737-1745; 2007.

36. Sackstein, R.; Merzaban, J. S.; Cain, D. W.; Dagia, N. M.; Spencer, J. A.; Lin, C. P.; Wohlgemuth, R. Ex vivo glycan engineering of CD44 programs human multipotent mesenchymal stromal cell trafficking to bone. Nat. Med. 14:181-187; 2008.

37. Schmidt, A.; Ladage, D.; Schinkothe, T.; Klausmann, U.; Ulrichs, C.; Klinz, F. J.; Brixius, K.; Arnhold, S.; Desai, B.; Mehlhorn, U.; Schwinger, R. H.; Staib, P.; Addicks, K.; Bloch, W. Basic fibroblast growth factor controls migration in human mesenchymal stem cells. Stem Cells 24:1750-1758; 2006.

38. Segers, V. F.; Van Riet, I.; Andries, L. J.; Lemmens, K.; Demolder, M. J.; De Becker, A. J.; Kockx, M. M.; De Keulenaer, G. W. Mesenchymal stem cell adhesion to cardiac microvascular endothelium: Activators and mechanisms. Am. J. Physiol. Heart Circ. Physiol. 290:H1370-1377; 2006.

39. Shi, H.; Patschan, D.; Dietz, G. P.; Bahr, M.; Plotkin, M.; Goligorsky, M. S. Glial cell line-derived neurotrophic growth factor increases motility and survival of cultured mesenchymal stem cells and ameliorates acute kidney injury. Am. J. Physiol. Renal Physiol. 294:F229-F235; 2008.

40. Singh, G. A possible cellular mechanism of cisplatininduced nephrotoxicity. Toxicology 58:71-80; 1989.

41. Togel, F.; Hu, Z.; Weiss, K.; Isaac, J.; Lange, C.; Westenfelder, C. Administered mesenchymal stem cells protect against ischemic acute renal failure through differentiationindependent mechanisms. Am. J. Physiol. Renal Physiol. 289:F31-F42; 2005.

42. Togel, F.; Isaac, J.; Hu, Z.; Weiss, K.; Westenfelder, C. Renal SDF-1 signals mobilization and homing of CXCR4positive cells to the kidney after ischemic injury. Kidney Int. 67:1772-1784; 2005.

43. Togel, F.; Weiss, K.; Yang, Y.; Hu, Z.; Zhang, P.; Westenfelder, C. Vasculotropic, paracrine actions of infused mesenchymal stem cells are important to the recovery from acute kidney injury. Am. J. Physiol. Renal Physiol. 292:F1626-F1635; 2007.

44. Toma, C.; Wagner, W. R.; Bowry, S.; Schwartz, A.; Villanueva, F. Fate of culture-expanded mesenchymal stem 
cells in the microvasculature: In vivo observations of cell kinetics. Circ. Res. 104:398-402; 2009.

45. Xinaris, C.; Imberti, B.; Remuzzi, G.; Morigi, M. Bone marrow mesenchymal stem cells in organ repair and strategies to optimize their efficacy. In: Goligorsky, M. S., ed. Regenerative Nephrology. London, UK: Academic Press; 2010:299-312.

46. Yagi, H.; Soto-Gutierrez, A.; Kitagawa, Y.; Tilles, A. W.; Tompkins, R. G.; Yarmush, M. L. Bone marrow mesenchymal stromal cells attenuate organ injury induced by LPS and burn. Cell Transplant. 19:823-830; 2010.
47. Yew, T. L.; Hung, Y. T.; Li, H. Y.; Chen, H. W.; Chen, L. L.; Tsai, K. S.; Chiou, S. H.; Chao, K. C.; Huang, T. F.; Chen, H. L.; Hung, S. C. Enhancement of wound healing by human multipotent stromal cell conditioned medium: The paracrine factors and p38MAPK activation. Cell Transplant. 20:693-706; 2011.

48. Zhang, Y.; Foudi, A.; Geay, J. F.; Berthebaud, M.; Buet, D.; Jarrier, P.; Jalil, A.; Vainchenker, W.; Louache, F. Intracellular localization and constitutive endocytosis of CXCR4 in human CD34 ${ }^{+}$hematopoietic progenitor cells. Stem Cells 22:1015-1029; 2004. 